\begin{tabular}{ccc}
\hline & International Journal of Engineering \& Technology, $7(2.7)(2018) 1104-1106$ \\
SPC & Website www.sciencepubco.com/index.php/IJET \\
Research paper & Technology \\
\hline
\end{tabular}

\title{
Investors' awareness towards commodities market with reference to GUNTUR city, Andhra Pradesh
}

\author{
Ch. Hymavathi ${ }^{1} *$, Kalpana Koneru ${ }^{1}$ \\ ${ }^{1}$ Assistant Professor, Department of Management Studies, VFSTR, Vadlamudi, Guntur (Dt). Andhra Pradesh \\ *Corresponding author E-mail: hyma.chunduri@gmail.com
}

\begin{abstract}
Commodity market is observed as an avenue to invest directly in trading markets. The study has aimed to evaluate investors trading habits, goals of investors, literacy and awareness level and emotional risk tolerance. Samples of 219 respondents are taken for this study. The study concludes the main aim of the investor to increase their wealth through commodity market which is one of the extended avenues for diversification.
\end{abstract}

Keywords: Trading Market; Investors; Commodity Market.

\section{Introduction}

Indian markets have already thrown open associate avenue for retail investors and traders to participate: in commodity market. For people who need to diversify their portfolios on the far side shares, bonds and realty, commodities square measure the simplest choice. Commodities really provide vast potential to become a separate plus category for market-savvy investors, arbitrageurs and speculators. Retail investors, United Nations agency claim to know the equity markets, might notice commodities a colossal market. However commodities square measure straightforward to know as so much as fundamentals of demand and provide square measure involved. Retail investors ought to perceive the risks associated blessings of mercantilism in commodities before creating an investment. Traditionally, evaluation in commodities futures has been less volatile compared with equity and bonds, so providing associate economical portfolio diversification choice like several different market, the one for commodity market plays a valuable role in info pooling and risk sharing. The market mediates between consumers and sellers of commodities, and facilitates choices associated with storage and consumption of commodities. Within the method, they create the underlying market additional liquid.

\section{Objectives of the study}

The main objective behind this research work is to find out the investor's awareness and perception about commodities in the current market scenario. It was conducted to find the potential of commodities in the coming near future.

The main purpose is to come out with those factors which make them hold to invest in commodity futures. It also tries to find out the trading frequency habits of the investors, goals, literacy and awareness level and their emotional risk tolerance.

\section{Research methodology}

\subsection{Sample and procedure}

The data used in this study was obtained from 219 investors who are engaged in this field.

Questionnaire was constructed based on the following aspects of trading

Years of participation in the commodity trading

- Gender wise

- Age wise.

- Education qualification wise

- Income wise

- Profession/occupation wise

\subsection{Hypothesis}

1) $\mathrm{H} 0=$ There is a significant relationship between gender wise classification and years of participation in this commodity trading

2) $\mathrm{H} 0=$ there is a significant relationship between age wise classification and years of participating in this commodities market.

3) $\mathrm{H} 0=$ There is a significant relationship between educational qualification and years of participation in this commodity trading

4) $\mathrm{H} 0=$ there is a significant relationship between income wise classification and years of participation in this commodity trading

5) $\mathrm{H} 0=$ There is a significant relationship between profession wise classification of respondents and years of participation in this commodity trading.

\subsection{Limitations of the study}

1) The study is limited to 219 respondents 
2) The survey is conducted only Guntur District in the state of Andhra Pradesh

\subsection{Analysis of the date}

a) Gender wise: Table 1 1indicates 88.1 percent of the respondents are male and 11.9 percent are female. But none of the respondents are Transgender. Most of the respondents are male because they are earning member of the family.

b) Age wise: Table 2 indicates 7.8 percent were below 25 years of age followed by 56.2 percent between 26 and 35 years, 26.5 percent between 36 and 50 years, 5.9 percent between 51 and 60 years and the rest 3.7 percent respondents were above 60 years of age. So, the largest numbers of respondents were in between 26 and 35years.

c) Educational qualification wise :Table 3 indicates the education wise classification of respondents revealed the fact that, 21.5 percent of the respondents were under graduate, followed by 43.4 percent were graduate , 21.5 percent were post graduate, and rest of the 13.7 percent were others. So, majority of the respondents were graduate

d) Income wise: Table 4 indicates 24.2 percent of respondents had monthly incomes Rs 10,000 to Rs 25,000 . 53percent of the respondents Rs 25,001 to $50,000,19.2$ percent of the respondents Rs 50,001 to Rs 75,000, 3.7 percent of the respondents Rs 75,001 to Rs $1,00,000$. Therefore, majority of the respondents are the people having income range between Rs 25001 to 50000

e) Professional/occupational wise: Table 5 indicates out of 219 respondents, 99 were professional, 34 were salaried class, 69 were business/ self-employed and 10 were student/ others. So majority of the respondents were professionals.

\subsection{Findings}

- $88.1 \%$ of respondents were males and $11.9 \%$ were females.

- The largest respondent is among 26 and 35 years old i.e., $56.2 \%$

- The majority of respondents completed high education (graduation) i.e., $43.4 \%$

- Most respondents had monthly income of among Rs 25,000 and Rs50, 000

- Most of the respondents were skill (professional) classes. i.e., 99 out of 219 .

\subsection{Suggestions}

The following suggestions are brought out on the basis of the result of the study.

1) As most respondents were men (88.1\%), effective measures were needed to encourage women and transgender people to invest in the commodity market.

2) Of the 219 respondents, nearly $56.2 \%$ were $26-35$ years old Therefore, an appropriate awareness program should be used to encourage the remaining age groups.

3) Of the 219 respondents, graduation is the highest qualification of investor education. Training programs can be made to increase this number.

The main aim of the investor to increase their wealth and commodity market is one of the extended avenues for diversification So investors should choose the right product to enter into the market on the basis of time ability skill. It helps to reduce the risk of their portfolio.

The government, stock exchange, and brokers shall conduct awareness programme regarding commodity trading in the urban and semi urban areas. It will help to develop the investor's literacy level.

\section{Results and analysis}

Table 1: Years of Participation in the Commodities Trading and Gender Wise Classification

\begin{tabular}{llll}
\hline Years of Participation & $\begin{array}{l}\text { Gender } \\
\text { Male }\end{array}$ & Female & Total \\
\hline Less than one year & 20 & 1 & 21 \\
Two to Three years & 109 & 15 & 124 \\
Three to Four Years & 38 & 4 & 42 \\
Five and above Years & 26 & 6 & 32 \\
Total & 193 & 26 & 219 \\
\hline
\end{tabular}

Table 2: The Results of Chi-Square Test for Table 1

\begin{tabular}{llll}
\hline $\begin{array}{l}\text { Calculated } \\
\text { Value }\end{array}$ & $\begin{array}{l}\text { Degree of } \\
\text { Freedom }\end{array}$ & $\begin{array}{l}\text { Asymptotic Sig- } \\
\text { nificance (2-sided) }\end{array}$ & $\begin{array}{l}\text { Level of Signif- } \\
\text { icance }\end{array}$ \\
\hline 2.689 & 3 & 0.442 & 0.005 \\
\hline
\end{tabular}

Since the calculated value of chi-square (2.689) is greater than the asymptotic significance (2-sided) (0.442) at 0.005 of level of significance 3 degrees of freedom. The Null hypothesis is rejected. So, there is a significant relationship between gender wise classification and years of participation in this commodities trading.

Table 3: Years of Participation in the Commodities Trading and Age Wise Classification

\begin{tabular}{|c|c|c|c|c|c|c|}
\hline $\begin{array}{l}\text { Years of Partici- } \\
\text { pation }\end{array}$ & \multicolumn{5}{|c|}{ Age (in Years) } & Total \\
\hline $\begin{array}{l}\text { Less than one } \\
\text { year }\end{array}$ & $\begin{array}{l}\text { Less } \\
\text { than } 25\end{array}$ & $\begin{array}{l}26- \\
35\end{array}$ & $\begin{array}{l}36- \\
50\end{array}$ & $\begin{array}{l}51- \\
60\end{array}$ & $\begin{array}{l}\text { Above } \\
60\end{array}$ & 21 \\
\hline $\begin{array}{l}\text { Two to Three } \\
\text { years }\end{array}$ & 8 & 8 & 3 & 2 & 0 & 124 \\
\hline $\begin{array}{l}\text { Three to Four } \\
\text { Years }\end{array}$ & 8 & 87 & 27 & 1 & 1 & 42 \\
\hline $\begin{array}{l}\text { Five and above } \\
\text { Years }\end{array}$ & 1 & 23 & 18 & 0 & 0 & 32 \\
\hline Total & $\begin{array}{l}0 \\
17 \\
\end{array}$ & $\begin{array}{l}5 \\
123 \\
\end{array}$ & $\begin{array}{l}10 \\
58\end{array}$ & $\begin{array}{l}10 \\
13 \\
\end{array}$ & $\begin{array}{l}7 \\
8 \\
\end{array}$ & 219 \\
\hline
\end{tabular}

Table 4: The Results of Chi-Square Test for Table 3

\begin{tabular}{llll}
$\begin{array}{l}\text { Calculated } \\
\text { Value }\end{array}$ & $\begin{array}{l}\text { Degree of } \\
\text { Freedom }\end{array}$ & $\begin{array}{l}\text { Asymptotic Signifi- } \\
\text { cance (2-sided) }\end{array}$ & $\begin{array}{l}\text { Level of Sig- } \\
\text { nificance }\end{array}$ \\
\hline 128.013 & 12 & 0.000 & 0.005 \\
\hline
\end{tabular}

Since the calculated value of chi-square (128.013) at 0.005 level of significance with 12 degrees of freedom. The Null hypothesis is rejected. So, there is significant relationship between age wise classification and years of participation in this commodities trading.

Table 5: Years of Participation in the Commodities Trading and Educational Qualification Wise Classification

\begin{tabular}{llllll}
\hline $\begin{array}{l}\text { Years of Par- } \\
\text { ticipation }\end{array}$ & $\begin{array}{l}\text { Educational Qualification } \\
\text { Under } \\
\text { Graduate }\end{array}$ & Graduate & $\begin{array}{l}\text { Post } \\
\text { Graduate }\end{array}$ & Others & Total \\
\hline $\begin{array}{l}\text { Less than one } \\
\text { year }\end{array}$ & 5 & 12 & 2 & 2 & 21 \\
$\begin{array}{l}\text { Two to Three } \\
\text { years }\end{array}$ & 30 & 51 & 30 & 13 & 124 \\
$\begin{array}{l}\text { Three to Four } \\
\begin{array}{l}\text { Years } \\
\text { Five and }\end{array}\end{array}$ & 9 & 18 & 9 & 6 & 42 \\
$\begin{array}{l}\text { above Years } \\
\text { Total }\end{array}$ & 3 & 14 & 6 & 9 & 32 \\
\hline
\end{tabular}

Table 6: The Results of Chi-Square Test for Table 5

\begin{tabular}{llll}
$\begin{array}{l}\text { Calculated } \\
\text { Value }\end{array}$ & $\begin{array}{l}\text { Degree of } \\
\text { Freedom }\end{array}$ & $\begin{array}{l}\text { Asymptotic Signifi- } \\
\text { cance (2-sided) }\end{array}$ & $\begin{array}{l}\text { Level of Sig- } \\
\text { nificance }\end{array}$ \\
\hline 11.739 & 9 & 0.228 & 0.005 \\
\hline
\end{tabular}

Since the calculated value of chi-square (11.739) is greater than the asymptotic significance 2 - sided $(0.228)$ at 0.005 level of significant with 9 degree of freedom. The Null hypothesis is rejected. So, there is significant relationship between educational qualification and years of participation in this commodities trading. 
Table 7: Years of Participation in the Commodities Trading and Monthly Income Wise Classification

\begin{tabular}{|c|c|c|c|c|c|}
\hline \multirow[b]{2}{*}{$\begin{array}{l}\text { Years of } \\
\text { Participation }\end{array}$} & \multicolumn{5}{|c|}{ Monthly Income } \\
\hline & $\begin{array}{l}\text { Rs } 10,000 \\
\text { to } \\
\text { Rs } 25,000\end{array}$ & $\begin{array}{l}\operatorname{Rs} 25,001 \\
\text { to } \\
\text { Rs50,000 }\end{array}$ & $\begin{array}{l}\text { Rs50,001 } \\
\text { to } \\
\text { Rs75,000 }\end{array}$ & $\begin{array}{l}\text { Rs } 75,001 \\
\text { to } \\
\operatorname{Rs} 1,00,000\end{array}$ & Total \\
\hline $\begin{array}{l}\text { Less than } \\
\text { one year }\end{array}$ & 11 & 5 & 4 & A $1,000,000$ & 21 \\
\hline $\begin{array}{l}\text { Two to } \\
\text { Three years }\end{array}$ & 31 & 74 & 18 & 1 & 124 \\
\hline $\begin{array}{l}\text { Three to } \\
\text { Four Years }\end{array}$ & 4 & 29 & 7 & 2 & 42 \\
\hline $\begin{array}{l}\text { Five and } \\
\text { above Years }\end{array}$ & 7 & 8 & 13 & 4 & 32 \\
\hline Total & 53 & 116 & 42 & 8 & 219 \\
\hline
\end{tabular}

Table 8: The Results of Chi-Square Test for Table 7

\begin{tabular}{llll}
\hline $\begin{array}{l}\text { Calculated } \\
\text { Value }\end{array}$ & $\begin{array}{l}\text { Degree of } \\
\text { Freedom }\end{array}$ & $\begin{array}{l}\text { Asymptotic Signifi- } \\
\text { cance (2-sided) }\end{array}$ & $\begin{array}{l}\text { Level of Sig- } \\
\text { nificance }\end{array}$ \\
\hline 40.971 & 9 & 0.000 & 0.005 \\
\hline
\end{tabular}

Since the calculated value of chi-square (40.971) is greater than the asymptotic significance 2 - sided (0.000) at 0.005 level of significant with 9 degree of freedom. The Null hypothesis is rejected. So, there is significant relationship between Income wise classification and years of participation in this commodities trading.

Table 9: Years of Participation in the Commodities Trading and Profession/ Occupation Wise Classification

\begin{tabular}{|c|c|c|c|c|c|c|}
\hline $\begin{array}{l}\text { Years of } \\
\text { Participa- }\end{array}$ & Professi & Dccupa & & & & To- \\
\hline $\begin{array}{l}\text { Less than } \\
\text { one year }\end{array}$ & $\begin{array}{l}\text { Profes- } \\
\text { sional }\end{array}$ & $\begin{array}{l}\text { Sala- } \\
\text { ried } \\
\text { Class }\end{array}$ & $\begin{array}{l}\text { Busi- } \\
\text { ness/ } \\
\text { Self- } \\
\text { em- } \\
\text { ployed }\end{array}$ & $\begin{array}{l}\text { Stu- } \\
\text { dents } \\
\& \\
\text { others } \\
\text { (speci- } \\
\text { fy) }\end{array}$ & $\begin{array}{l}\text { Re- } \\
\text { tired }\end{array}$ & 21 \\
\hline $\begin{array}{l}\text { Two to } \\
\text { Three } \\
\text { years }\end{array}$ & 9 & 3 & 5 & 4 & 0 & 124 \\
\hline $\begin{array}{l}\text { Three to } \\
\text { Four } \\
\text { Years }\end{array}$ & 66 & 22 & 31 & 5 & 0 & 42 \\
\hline $\begin{array}{l}\text { Five and } \\
\text { above } \\
\text { Years }\end{array}$ & 22 & 5 & 14 & 0 & 1 & 32 \\
\hline Total & $\begin{array}{l}2 \\
99\end{array}$ & $\begin{array}{l}4 \\
34\end{array}$ & $\begin{array}{l}19 \\
69\end{array}$ & $\begin{array}{l}1 \\
10\end{array}$ & $\begin{array}{l}6 \\
7\end{array}$ & \\
\hline
\end{tabular}

Table 10: The Results of Chi-Square Test for Table 9

\begin{tabular}{llll}
\hline $\begin{array}{l}\text { Calculated } \\
\text { Value }\end{array}$ & $\begin{array}{l}\text { Degree of } \\
\text { Freedom }\end{array}$ & $\begin{array}{l}\text { Asymptotic Signifi- } \\
\text { cance (2-sided) }\end{array}$ & $\begin{array}{l}\text { Level of Sig- } \\
\text { nificance }\end{array}$ \\
\hline 64.688 & 12 & 0.000 & 0.005 \\
\hline
\end{tabular}

Since the calculated value of chi-square (64.688) is higher than the asymptotic significance 2-sided (0.000) at 0.005 level of significant with a degree of freedom. The Null hypothesis is rejected. So, there is a significant relationship between profession wise classification of respondents and years of participation in this commodities trading.

\section{Conclusion}

Commodity market has shown tremendous development in the last decade and also has a long history in our country. The market has seen ups and downs. The policy maker if they update the policy periodically, it will help to protect the interest of the investors.

\section{References}

[1] Acharya, Viral V., Lars A. Lochstoer, and Tarun Ramadorai. "Limits to arbitrage and hedging: Evidence from commodity markets." Journal of Financial Economics 109, no. 2 (2013): 441-465.

[2] Adrian, Tobias, Erkko Etula, and Tyler Muir. "Financial Intermediaries and the Cross-Section of Asset Returns." The Journal of Finance 69, no. 6 (2014): 2557-2596.

[3] Henderson, Brian J., Neil D. Pearson, and Li Wang. "New evidence on the financialization of commodity markets." The Review of Financial Studies 28, no. 5 (2014): 1285-1311.

[4] Ouchi, William G. "A conceptual framework for the design of organizational control mechanisms." In Readings in accounting for management control, pp. 63-82. Springer, Boston, MA, 1979.

[5] Mou, Yiqun. "Limits to arbitrage and commodity index investment: front-running the Goldman roll." (2010).

[6] Jegadeesh, Narasimhan, and Sheridan Titman. "Returns to buying winners and selling losers: Implications for stock market efficiency." The Journal of finance 48, no. 1 (1993): 65-91

[7] Brunetti, C., and D. Reiffen. "Commodity Index Trading and Hedging Costs, Division of Research \& Statistics and Monetary Affairs." Washington DC: Federal Reserve Board (2011).

[8] Basak, Suleyman, and Anna Pavlova. "A model of financialization of commodities." The Journal of Finance 71, no. 4 (2016): 1511 1556.

[9] Bos, Jaap, and Maarten van der Molen. "A bitter brew? Futures speculation and commodity prices." (2012).

[10] Bank, Barclays Investment. "The commodity investor." (2013): 2011-57.

[11] Cheng, Ing-Haw, and Wei Xiong. "Financialization of commodity markets." Annu. Rev. Financ. Econ. 6, no. 1 (2014): 419-441.

[12] Etula, Erkko. "Broker-dealer risk appetite and commodity returns." Journal of Financial Econometrics 11, no. 3 (2013): 486-521.

[13] Gilbert, Christopher L., and C. Wyn Morgan. "Food price volatility." Philosophical Transactions of the Royal Society of London B: Biological Sciences 365, no. 1554 (2010): 3023-3034.

[14] Haase, Marco, Yvonne Seiler Zimmermann, and Heinz Zimmermann. "The impact of speculation on commodity futures markets-A review of the findings of 100 empirical studies." Journal of Commodity Markets 3, no. 1 (2016): 1-15. 